\title{
Anaerobic Co-digestion of Organic Fraction of Municipal Solid waste and Septage for Sustainable Waste Treatment: A Case Study from Goa, India
}

\author{
Ravikiran Shet and Srikanth Mutnuri
}

\section{ABSTRACT}

\begin{abstract}
India generates 0.15 million metric tons (MT) of solid waste per day out of which more than $80 \%$ is organic fraction. Apart from this, $38 \%$ of the households use septic tanks where proper disposal of faecal sludge is also need of the hour. Anaerobic co-digestion (ACD) of two different substrates has positive potential towards solving this problem. In the present study, ACD of organic fraction of municipal solid waste (OFMSW) and septage solids (SS) was studied at three different levels, i.e., lab-scale, pilot-scale $\left(1 \mathrm{~m}^{3}\right)$, and full scale- capacity $\left(325 \mathrm{~m}^{3}\right)$. A loading rate of $1.5 \mathrm{~kg} \mathrm{VS} / \mathrm{m}^{3}$ was selected. The bio-methanation potential (BMP) assay showed a maximum biogas generation, i.e., $120 \pm 20.6$ $\mathrm{mL} / \mathrm{gmVS}$ with $68 \%$ maximum methane concentration at a 5:1 OFMSW and SS ratio. Cumulative biogas production after 30 days was 1.6 L/gmVS. The ultimate biogas production in the pilot-scale plant was $1000 \pm 100.5 \mathrm{~L} /$ day with $71 \%$ methane. The plant was also efficient in removing $87 \%$ of COD and $61 \%$ of VS. The full-scale anaerobic digester was set up at Mormugao Municpal Council, Goa India wherein the objective was to co-digest OFMSW and SS. This digester showed a similar removal pattern like earlier studies i.e., 94\% and $45 \%$ COD and VS removal, respectively. The average methane content of the biogas was $68 \%$. Full-scale operation of the anaerobic digester did not show any operational problems at the chosen co-digestion conditions.
\end{abstract}

Keywords: anaerobic co-digestion, biogas, BMP assay, organic fraction of municipal solid waste, septage, solid waste management.
Published Online: August 25, 2021

ISSN: $2736-5506$

DOI : $10.24018 /$ ejenergy.2021.1.3.15

Ravikiran Shet

Applied Environmental Biotechnology Laboratory, BITS Pilani, KK. Birla Goa Campus, NH 17B, Zuarinagar, Goa, India.

(e-mail: kravikiranshet@gmail.com)

Srikanth Mutnuri*

Applied Environmental Biotechnology Laboratory, BITS Pilani, KK. Birla Goa Campus, NH 17B, Zuarinagar, Goa, India. (e-mail: srikanth@goa.bits-pilani.ac.in)

*Corresponding Author

\section{INTRODUCTION}

India is the second most populous country in the world and fourth biggest consumers of energy worldwide. The per capita energy consumption of the growing population in India is increasing day by day [1]. By 2022, India plans to install $175 \mathrm{GW}$ of renewable energy capacity, of that, $10 \mathrm{GW}$ will be bio power. The flexibility and storage capacity of biogas make it an ideal contender for achieving these goals [2]. Also improper solid waste management and deficiencies in sanitation form a major environmental and health threat in Indian cities [3]. Urban household (around $38 \%$ ) are using septic tanks and community toilet complexes (CTC's) for their daily needs. The often used septic tanks are devoid of any kind of treatment for septage/fecal sludge or environmentally sound disposal systems. Total quantity of solid waste generated in urban areas of the country is about 0.15 million MT per day out of which approximately 85-90 $\%$ of solid waste is untreated and disposed-off on land [4]. Unscientific treatment and disposal of such large quantities of septage imposes major threats in Indian cities leading to environment and surface water pollution [5].In last couple of decades, Anaerobic Co-digestion(ACD) of different substrates has been regarded as most significant technology having potential for renewable energy and nutrient rich organic fertilizer production in a sustainable manner [4].

Septage is rich in nitrogen and trace elements but sometimes low in biodegradable organic matter [3], [6]. Hence biomethane potential (BMP) is very low. Along with the septage, readily available organic waste substrate in the urban areas, in sufficient quantity, is the Organic fraction of the Municipal solid waste (OFMSW). Treating both septage and OFMSW is a major problem in India today.

OFMSW is a rich source of volatile solids (>90\%), which help in easy conversion to methane using an anaerobic process [3]. High lipid and oil content present in OFMSW contributes to higher methane and $\mathrm{CO}_{2}$ generation [7], while the carbohydrates yield direct methane [8]. Increased biogas and methane production and improved digester performance, including higher substrate degradation efficiencies, were observed when trace elements were present [9].which can be achieved by digesting two different substrates such as OFMSW and SS. ACD is the process of digesting two separate waste streams in a single bioreactor. In co-digestion, the favorable wastes improve stabilization of the biological system and during the process complex wastes are 'codigested". ACD has proven to improve digester operating 
characteristics and end performance both by increasing gas production and solid destruction [6].

The present study was carried out at Mormugao (Vascoda-Gama), Goa, India, a city located at $15.3982^{\circ} \mathrm{N}, 73.8113^{\circ}$ E, with a population of 97154 (as per 2001 census). According to the Goa State Pollution Control Board (GSPCB), Mormugao Municipal Council generates 45Tons of municipal solid waste (MSW) per day, and about 19MT of the total waste is biodegradable and organic. Another sort of garbage that the city must cope with is septage. Which on a daily basis, about $80 \mathrm{~m}^{3}$ are generated [10]. Hence the need arises for a sustainable and feasible treatment system for the waste generated within the city. The combined treatment of OFMSW and SS has the advantage of treating two waste streams together scientifically. Apart from treating the wastes, there is potential for nutrient recovery and energy generation [11]. The spent digestate after the AD process has potential use in agriculture as an alternative for existing chemical fertilizers.

Bio-methanation potential (BMP) assay provides a measure of the anaerobic digestibility of a given substrate. The use of BMP assay offers a relatively inexpensive and repeatable method to make relative comparisons of the anaerobic digestibility and potential biogas production between various substrates [12]. BMP assay was used to determine the amount of organic carbon that could be converted in to methane anaerobically in a given sample [13].

In the present study, a bio-methanation potential assay of different ratios of OFMSW and SS admixtures was carried out. The results obtained in anaerobic co-digestion studies were validated at pilot-scale $\left(1 \mathrm{~m}^{3}\right)$ before implementing at full scale $\left(350 \mathrm{~m}^{3}\right)$ in Mormogao Municipal council.

\section{MATERIALS AND METHODS}

\section{A. Substrates Characteristics}

The OFMSW was collected from the hostel cafeteria of BITS Pilani Goa Campus daily for the lab scale and pilot scale studies. The OFMSW mainly consisted of leftover cooked food (rice, pulses, etc.), and raw leafy vegetables. The solids from septic tankers were collected by using unplanted drying beds (approximately $8 \% \mathrm{w} / \mathrm{w}$ of total solids (TS). For the full-scale plant, OFMSW was from the Sada waste dumping site of Mormugao Municipal Council (MMC). The full-scale plant was also installed at the same dumping site. The segregated organic fraction from the municipal solid waste (approximately $11 \% \mathrm{w} / \mathrm{w}$ TS) was used as the substrate, mainly obtained from the Mormugao city hotels. The collected waste was segregated manually to remove the inorganics such as plastics, metals, etc., and 3HP macerator was used to get a particle size between 3 to $5 \mathrm{~mm}$ before feeding. The mesophilic inoculum was obtained from the existing biogas plant on the campus and used for BMP assay and pilot-scale study. The inoculum was incubated for 15 days to remove the effect of residual organic matter present. The digestate from the existing biogas plant and locally procured cow dung was used as inoculum for the full-scale biogas plant.

\section{B. Laboratory Scale Bio-methanation Potential Assay}

Bio-methanation potential (BMP) assays were conducted in $130 \mathrm{~mL}$ serum bottles capped with butyl rubber septa. BMP assays were set up to determine the feeding rate of the digester and subsequent gas output. BMP assay with different OFMSW and SS admixtures in the ratios 1:1, 2:1, 3:1, 4:1, and 5:1 were employed. Digestate from an existing biogas plant was used as the inoculum, and the experiments were conducted at $1.5 \mathrm{gmVS} / \mathrm{kg}$ organic loading rate for 33 days. Bottles with 5\% ethanol and only digestate served as positive and negative controls, respectively. The setup was maintained at room temperature under anaerobic conditions. The quantity of biogas produced was measured daily by water displacement method. The composition of the biogas was analysed by gas chromatography (GC), Trace 1110 (Thermofisher Scientific, Mumbai, India), equipped with a thermal conductivity detector (TCD), and hydrogen as the carrier gas. A packed stainless steel column was used, having solid support of a spherocarb, length $2 \mathrm{~m}$; diameter $1 / 8$ th. The GC oven temperature was programmed to increase from 60 ${ }^{\circ} \mathrm{C}$ to $120{ }^{\circ} \mathrm{C}$ at the rate of $5{ }^{\circ} \mathrm{C}$ per min. The temperatures of the injector and detector were at $150{ }^{\circ} \mathrm{C}$ and $183{ }^{\circ} \mathrm{C}$, respectively [14].

\section{Pilot-scale Anaerobic Co-digestion of OFMSW and SS}

The digester was a cylindrical tank made of HDPE plastic with a height of $2 \mathrm{~m}$ and a diameter of $1 \mathrm{~m}$ with a total fill-up volume of $1500 \mathrm{~L}$. Inlet was provided at the top and outlet at $1.6 \mathrm{~m}$ from the bottom with reactor volume to gas holding volume of 75:25 ratios. The reactor contents were mixed for $20 \mathrm{~min}$ a day by recirculating the slurry from the outlet to the inlet of the reactor using $1 \mathrm{HP}$ pump. The reactor was fed with the substrate (OFMSW and SS) manually from the top inlet. Two similar reactors were set up: one with OFMSW and another with a mixture of OFMSW and SS as feed. Initially, the reactors were fed with inoculum from an existing anaerobic digester. No feeding was carried out for the first week. The feeding was started in both the reactors with OFMSW at $25 \%$ capacity for four days. The feeding was increased gradually and reached the full loading capacity after seven days. After one week, the substrate quantity was increased to $12 \mathrm{~kg} /$ day (1.5 kg VS/day). This substrate load was the total OFMSW available per day for the biogas reactor operation. After one month of the reactor running only on OFMSW, $2 \mathrm{~kg} / \mathrm{day}$ of the SS was introduced in to one of reactor to get a feed ratio of 5:1 (with $10 \mathrm{~kg}$ of OFMSW and $2 \mathrm{~kg}$ of SS). The feed was homogenised manually before feeding. The other reactor was operated only with OFMSW. In both cases, the loading rate maintained was between 1.5 to $2 \mathrm{Kg} \mathrm{VS} / \mathrm{m}^{3}$. SS was obtained after separating the solids from the liquid by using an unplanted drying bed. The hydraulic retention time (HRT) was maintained at 43 days. Mixing was carried out by circulating the contents of the reactors using a slurry pump. The generated biogas was stored in $1.5 \mathrm{~m}^{3}$ balloon, and the biogas was flared before leaving to the atmosphere. The schematic drawings of the reactors are presented in Fig 1. The composition of the biogas was analysed by Geotech BIOGAS 5000 portable biogas analyser. 


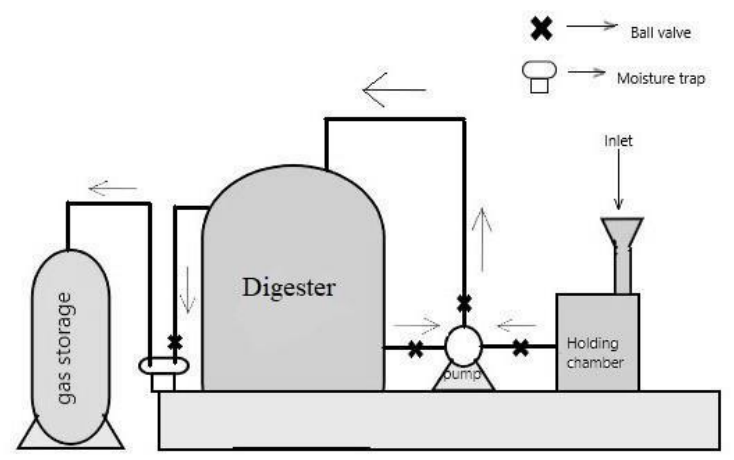

Fig. 1. Graphical representation of the pilot scale plant.

\section{Full-scale Anaerobic Co-digestion of OFMSW and Septage}

A full-scale plant of 5 ton/day capacity plant was constructed at the $1500 \mathrm{~m}^{2}$ land given by Mormugao Municipal Corporation, Mormugao, Vasco-da-Gama Goa, having geographical coordinates $15^{\circ} 24^{\prime} 09^{\prime \prime} \mathrm{N} 73^{\circ} 47^{\prime} 23^{\prime \prime} \mathrm{E}$.

A full-scale plant was setup with two digesters of size $320 \mathrm{~m}^{3}$ each, with a total working volume of $280 \mathrm{~m}^{3}$ capable of handling 6 tons of waste per day with HRT of 43 days. The reactor is cylindrical made of zinc-aluminium alloy with an inner HDPE liner. The reactor has a height of $5 \mathrm{~m}$ and a diameter of $9 \mathrm{~m}$ with a total fill volume of $330 \mathrm{~m}^{3}$. Inlet was provided at $4.6 \mathrm{~m}$ height and outlet at $4.4 \mathrm{~m}$ from the bottom with reactor volume to gas holding volume of $85: 15$ ratios. The generated gas was collected in $100 \mathrm{~m}^{3}$ balloons. The mixing was carried out with the help of radial impellers provided inside the reactors for $4 \mathrm{hr}$ every day [4]. The reactor was fed with the substrate (OFMSW and SS) using a pump. The local municipal authorities provided the segregated OFMSW and the substrate was macerated using a $3 \mathrm{HP}$ mechanical macerator to obtain the particle size between 3 to $5 \mathrm{~mm}$. Initially, the reactors were fed fresh cow dung slurry and inoculum from an existing anaerobic digester. No feed conditions were maintained for first 15days after which the reactors were fed with OFMSW at $25 \%$ of total capacity for next 15 days. After three week of operation the substrate quantity was increased to an average of $1500 \mathrm{~kg} /$ day (1.4 $\mathrm{kgVS} /$ day). This substrate quantity was the total OFMSW available per day on which the biogas reactor was working. After 45 days of the reactor running on OFMSW, $400 \mathrm{~kg} /$ day of the SS was added to the reactor. Septage was brought by the septic tankers, which collect household septage. SS were separated using unplanted drying beds. The OFMSW and SS in the ratio of 5:1 was fed into a macerator, which was later pumped into the reactors. The spent digestate was passed through unplanted drying beds to separate solids. The collected biogas was passed through $\mathrm{CO}_{2}$ and $\mathrm{H}_{2} \mathrm{~S}$ scrubbers to enrich the purity of methane. The enriched biogas was stored and used for electricity generation using $42 \mathrm{~kW}$ methane-based generators procured from Kirloskar, India. The process flowchart is shown in Fig. 2.

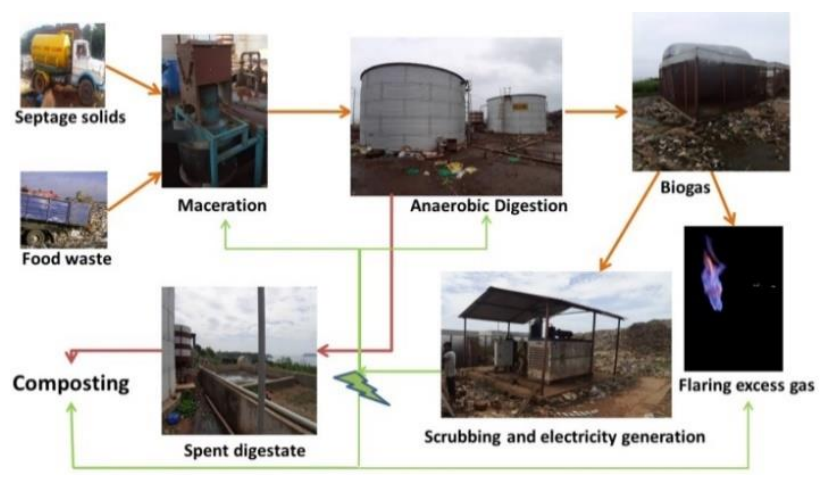

Fig. 2. Process flowchart of full-scale biogas plant at Vasco, Goa.

\section{E. Sampling and Analysis}

Various physicochemical parameters were analyzed for the substrates and digestate samples namely, chemical oxygen demand (COD), pH, total solids (TS), volatile solids (VS), volatile fatty acids (VFA), total alkalinity (TA), total ammoniacal nitrogen (TAN), and phosphorous (P). The COD was analyzed using the closed reflux colorimetric method (APHA method 5220 D). Whereas TA was measured using the titration method (APHA method, 2320 B). P was estimated by the vanadomolybdophosphoric acid colorimetric method (APHA method 4500-P-C). TAN was assessed using the distillation method with Kel-plus distillation unit (APHA method $4500 \mathrm{NH}_{3}$ ) [15-17]. Both $\mathrm{pH}$ and conductivity were measured using Oaklon PCTSTestr ${ }^{\mathrm{TM}}$ 50. The biogas generated was analyzed using Gas Chromatography (Thermo scientific tracer 1110) equipped with thermal conductivity detector (TCD). The analysis was performed every $8^{\text {th }}$ day for each substrate separately, i.e., 5:1 admixture and the digestate from both pilot and full-scale plants. All the analysis was done in triplicates.

\section{F. Statistical Analysis}

All the values represent mean value and mean standard error at $n=2$. Data was checked for normality and homogeneity of variance. Percentage data were arcsine transformed. One-way ANOVA was carried with treatments as a fixed factor on the removal of COD, TS, VS and TKN. All statistical analysis (comparison between treatments and means) was performed using IBM SPSS v23 (IBM, USA) data analysis software package. For the statistical efficiency analysis of the different parameters at the inlet and outlet, $\Delta \mathrm{p}$ was built for each parameter with significance level of $\mathrm{p}<$ 0.05 .

\section{RESUlTS AND DISCUSSIONS}

\section{A. Characterization of OFMSW and SS}

All physicochemical parameters (COD, pH, TS, VS, VFA, TA, TAN, conductivity, and P) quantified for OFMSW (for pilot and full scale) and SS, are shown in Table 1. The OFMSW used in the full-scale study was considerably different from the one used in pilot scale in terms of composition which consisted of leafy and raw vegetables along with cooked food. The difference is due to the presence of straw, grass cuttings and banana leaves in the OFMSW of the market used in the full-scale study. 


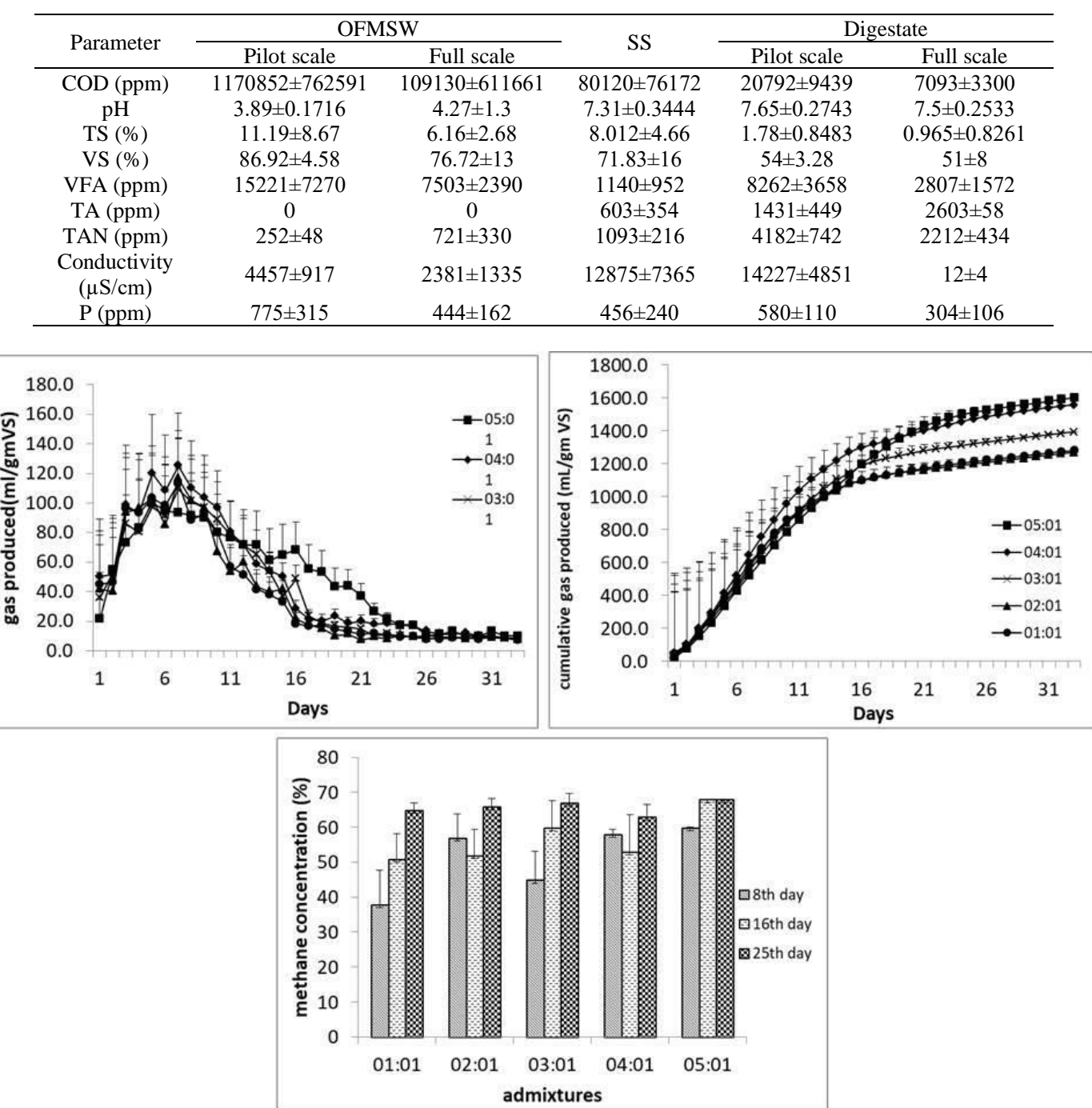

Fig. 3. (a) Daily biogas production, (b) Cumulative biogas production and (c) Methane concentration in $\%$.

\section{B. Laboratory scale BMP Assay}

BMP analysis was set up to understand the dynamics and gas production rate for different OFMSW and SS admixtures, an essential criterion to fix the reactor feeding rates and subsequent gas output. The BMP assay provides a measure of the anaerobic digestibility of a given substrate.

The biogas generation from the setup was monitored for 30 days. The bell-shaped curve in Fig. 3 (a) indicates an initial gradual increase in biogas generation. The highest peak was attained between the $4^{\text {th }}$ and $7^{\text {th }}$ day for all the admixtures. The initial increase seen in the graph in biogas production was due to the high organic load. In contrast, the peak was reached when the optimum substrate to organism ratio was attained. Eventually, the substrate concentration reduced, and hence a drop in the quantity of biogas generation was observed. The highest biogas generation seen for 4:1 and 5:1 admixture was $120 \pm 20.6$ and $100 \pm 15.8 \mathrm{~mL} / \mathrm{gmVS}$. The admixture with 5:1 ratio was chosen for further studies as it showed highest biogas production for the extended period of time with a cumulative biogas of $1.63 \mathrm{~L} \mathrm{Fig.} 3$ (b) which indicates that the 5:1 ratio is better compared to other admixtures [18]. Based on post-hoc studies there was no variation in the gas production was seen for $1: 1$ and $2: 1$ however 5:1 showed highest biogas generation with significant variation $(\mathrm{p}<0.05)$. The methane concentration in the biogas was measured every $8^{\text {th }}$ day (Fig. 3 (c)) with highest percentage of methane in the
5:1 (68\% purity) admixture with $133 \mathrm{~L} / \mathrm{kgVS}$ biogas, which was also a requisite for choosing 5:1 admixtures ratio for pilot and full scale studies. With the BMP studies of co-digestion, we could establish the ratio of mixture of OFMSW and SS.

\section{Pilot-scale Anaerobic Co-digestion of OFMSW and SS}

We carried out fed batch studies in $1 \mathrm{~m}^{3}$ reactors before full scale implementation. The $1 \mathrm{~m}^{3}$ reactor was operated for 64 days. The biogas generation and methane concentration-time plot shown in Fig 4. The results achieved were similar to that achieved in the BMP assay, i.e., a gradual increase in biogas production. The system attained stable biogas production after 22 days with an optimum biogas production of $1000 \pm 100.5 \mathrm{~L} / \mathrm{kgVS} /$ day. The methane concentration hovered around $30 \%$ at the initial 10 days, due to dormant microbial population and residual oxygen. However, it soared to an average of $70 \%$ showing optimum bio-methanation as the digestion progressed which corresponds to the results from literature $[4,19,20]$. The average biogas yield was found to be $910 \mathrm{~L} / \mathrm{kgVS}_{\text {added }} /$ day. The study conducted by Stan et al., showed that a $2 \mathrm{~m}^{3}$ capacity reactor run in a batch process has yielded highest of $0.8 \mathrm{~m}^{3}$ biogas/day with $150 \mathrm{~kg}$ of feed consisting of cooked food leftovers, raw fruits and vegetables, which correlates with the results obtained from the present study [20].

The pilot scale system was efficient in consuming $87 \%$ of input COD from the system. Also, $61 \%$ of VS reduction was 
observed in this process $(\mathrm{P}<0.05)$ (Table 1). The research conducted by Sheng et al. determined TAN $>5 \mathrm{~g} / \mathrm{L}$ affects the purity of the biogas. However, in the present study, a spike was seen in TAN. It did not result in the inhibition of biogas generation [21], [22], but a drop in methane concentration was seen after 50 days of operation which is believed to be caused by the accumulation on TAN in the system [23]. No TA was seen in OFMSW and 5:1 admixture, but the concentration fluctuated between $3000 \pm 760$ to $5000 \pm 995$ $\mathrm{ppm}$ in the digestate. The decrease in VFA was seen for digestate as compared with OFMSW. The $\mathrm{pH}$ of the digestate was around 7 as per the discharge norms. The study conducted by Marín-Peña et al. showed the effect of conductivity on biogas generation concluded that conductivity above $14 \mathrm{mS} / \mathrm{cm}$ is ideal for the reactors. In the present study, conductivity gradually increased to an average of 15 to $30 \mu \mathrm{S} / \mathrm{cm}$ after $16^{\text {th }}$ day and was remained constant for the rest of the process [24].

\section{Full-scale Anaerobic Co-digestion of OFMSW and Septage}

Based on the results obtained at pilot scale, two modules of full-scale anaerobic digester of CSTR type (320cu.m each) was constructed at SADA waste dumping site of Mormugao municipal council and operated for 30 weeks.

Fig. 5 shows the total daily feed and the corresponding methane concentration in the generated biogas. Ten days no feed data (for maintenance purposes) showed a decline in methane concentration from 65 to $45 \%$ on day 141 . However, the purity increased as the feeding was restarted with no additional time for recovery. The average gas produced was found to be $500 \mathrm{~L} / \mathrm{kg} \mathrm{VS}$ added $/$ day. The difference in the average biogas produced in both pilot and full scale was relatively high mainly due to the difference in the composition of the OFMSW at the Municipal council level which had grass, large banana leaves and some inorganics due to improper and poor segregation. Theoretically, a fullscale plant should produce $100 \mathrm{~m}^{3}$ of biogas for the similar 1 ton/day feed. Whereas the present study yielded an average of $50 \mathrm{~m}^{3}$ of biogas for every ton of feed which may be because of inefficient segregation, under design of the impellers. When compared to the research carried out by Angeli et al which showed $25 \mathrm{~m}^{3}$ biogas generation/day with 3 tons/day of feed (SS and OFMSW) at mesophilic conditions, the present full scale reactor has yielded a $50 \%$ higher biogas [19].

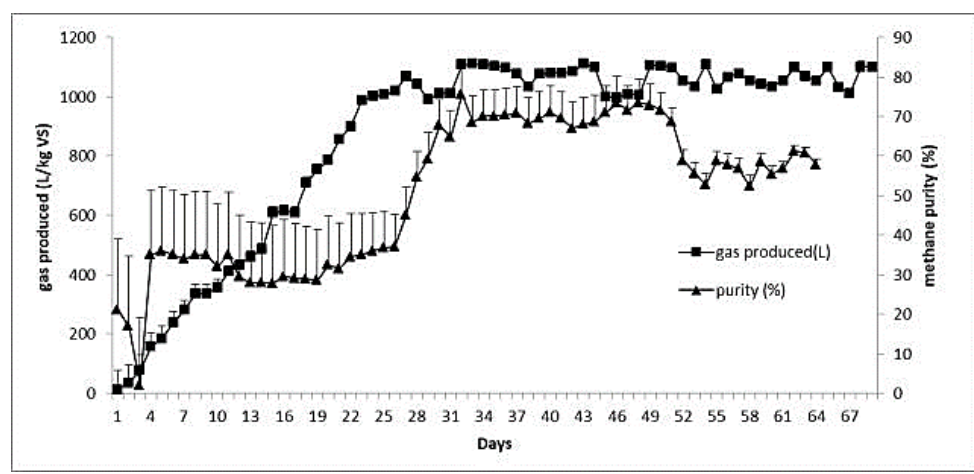

Fig. 4. Pilot scale biogas generation.

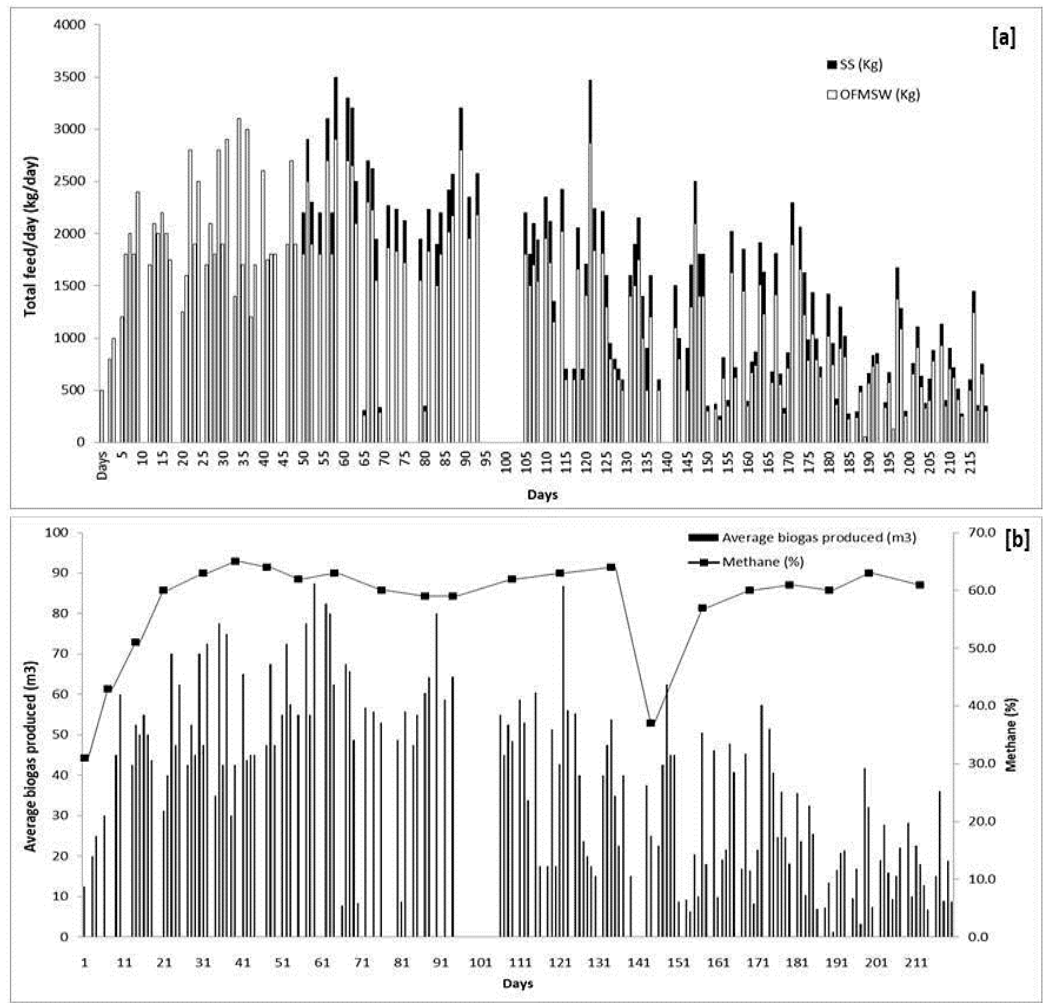

Fig. 5(a). Showing daily feed to the full-scale plant and (b) biogas generation and purity in full scale plant. 

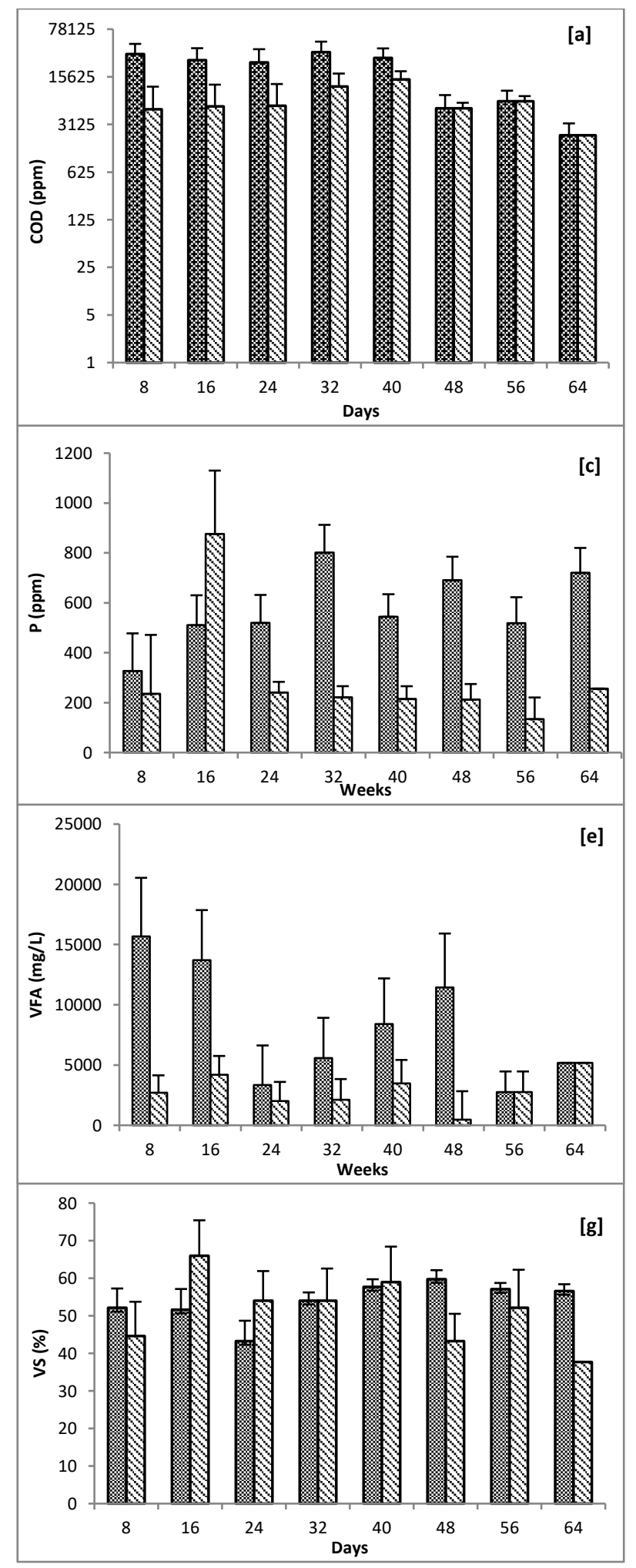

Qpilot scale
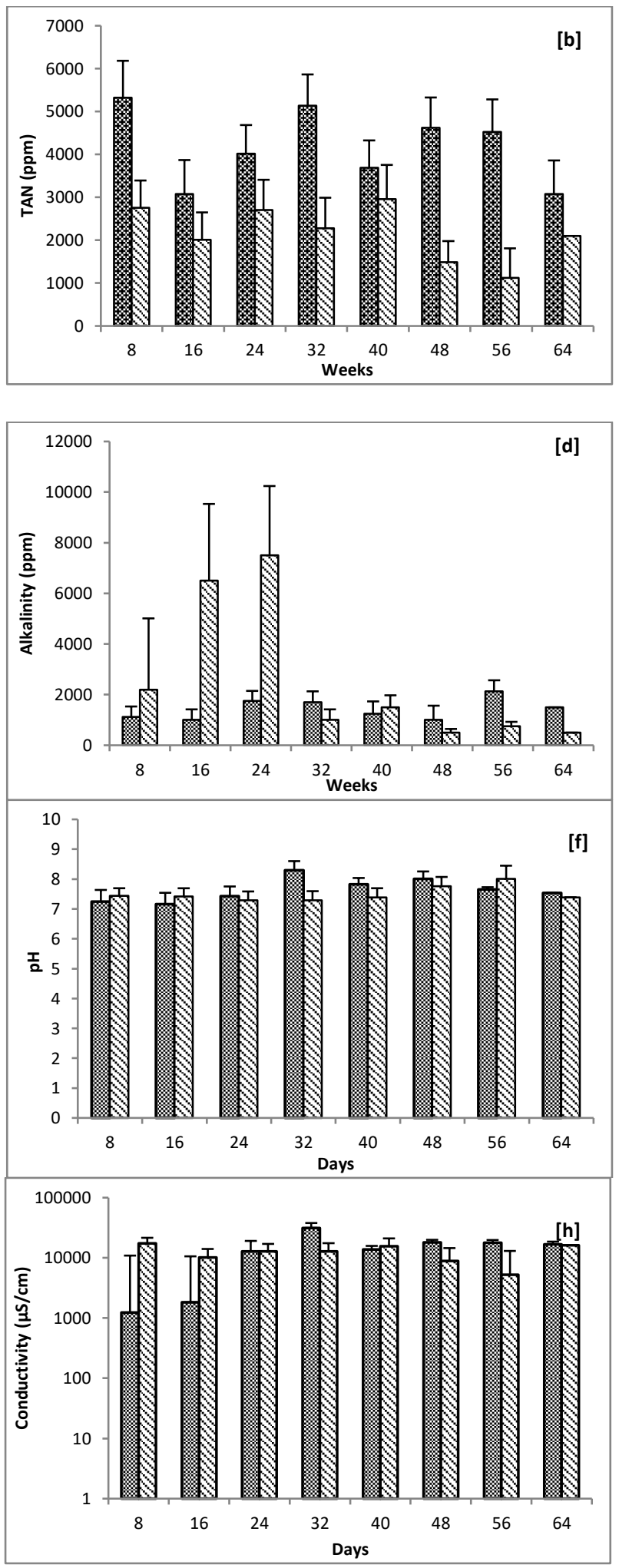

口large scale

Fig. 6. Showing weekly variations in parameters (a) COD, (b) TAN, (c) P, (d) Alkalinity, (e) VFA, (f) pH, (g) Conductivity, and (h) VS for pilot and full-scale plant.

The average reduction in COD and VS due to OFMSW digestion was $94 \%$ and $45 \%$, respectively $(p<0.05)$. As observed in pilot-scale (Fig. 6 (b)), the average TAN concentration was increasing and the concentration remained constant in cas of full-scale study, however in both cases the concentration remained within the threshold value and no inhibitory actions on biogas generation were observed [22]. A continuous 55\% decrease in $\mathrm{P}$ was seen after the 24th day of digestion of the 5:1 admixture. TA was found to be ranging from $2000 \pm 1897$ to $7000 \pm 1346$ ppm, as shown in Fig 6 (d), started decreasing after the $30^{\text {th }}$ day - a possible rationale for reduced methane concentration [25].

VFA was seen to be varying from $1000 \pm 922.45$ to $5000 \pm 956.98 \mathrm{ppm}$, and the VFA/TA ratio was between 0.5 to 0.6 , which indicates slight system overloading as stated in work carried out by Lin et al., and Gao et al. The $\mathrm{pH}$ was between 7 to 8 , indicating healthy conditions for allowing optimum microbial growth. The maximum conductivity was 
found to be $18 \pm 4.5 \mathrm{mS} / \mathrm{cm}$, which is less than the threshold for any inhibitory action to take place by the changing electron transport pathways [21], [24].

\section{CONCLUSIONS}

For an urban city in India, municipal corporations have to find a sustainable solution to handle municipal solid waste that is generated as well as the septic tankers which bring in septage from the household septic tanks from the cities. Usually the septage will be jettisoned into the Centralized sewage treatment plants. These centralized sewage treatment plants generally rely on conventional treatment processes such as activated sludge (AS) or sequencing batch reactors. Though these systems achieves sufficiently low carbon, nitrogen, and phosphorus effluent levels, they are not costeffective, hardly performs recovery, requires electricity equivalent to a fossil fuel consumption of $85 \mathrm{kWh}$ per inhabitant equivalent (IE) per year, and has an operational $\mathrm{CO}_{2}$ footprint of $80 \mathrm{~kg} \mathrm{CO}_{2} \mathrm{IE}^{-1} /$ year [26], [27]. Projected water and phosphorus shortages and the need to lower greenhouse emissions forces us to rethink solid waste treatment and energy production for a sustainable future [28].

The co-digestion of OFMSW and SS has shown positive effects on biogas production. The study focused on the treatment of OFMSW and SS largely for waste minimization and at the same time scientific treatment of two different wastes. The results thus obtained reflect the proposed aim of the study. Studies carried out by Klein et al, and Marín-Peña et al showed that the conductivity of more than $30 \mathrm{mS} / \mathrm{cm}$ has shown an adverse effect on the biogas system [24], [29]. However, in this study, it was seen that the conductivity never exceeded the threshold value making the system efficient and also proving the fact that the OFMSW and SS can be mixed at 5: 1 ratio.

The deviations in the results of full scale plant from the BMP assay and pilot scale reactor were due to manual operational errors such as improper segregation and inadequate availability of the OFMSW and difference in the composition of the OFMSW at the full scale level. The major challenge at full scale operations of the anaerobic digesters is proper segregation of organic waste.

Approximately 400 to $500 \mathrm{kWh}$ of energy per day can be generated, which is ample for the plant operation. The electricity produced can be utilized for the plant operation such as maceration, pumping, mixing, etc. Hence, no external source of power was required to run a full-scale plant. The spent digestate obtained from the system can be converted into Phosphate rich organic manure (PROM) which is recognized by the Fertilizer control order of Government of India which remains the focus of our future work.

\section{ACKNOWLEDGMENT}

The authors are thankful to Department of Biotechnology (DBT), New Delhi, India for financial assistance for a research project titled "Demonstration of waste-to-energy project by anaerobic co-digestion of food waste and septage" (BT/PR22594/PBD/26/657/2016). Authors would also like to thank BITS Pilani, K.K. Birla Goa Campus, for providing all the facilities to carry out the work.

\section{REFERENCES}

[1] Government_of_India. Ministry of statistics and programme implementation 2011 [Available from: http://www.mospi.nic.in/.

[2] Ministry of Urban Development I. 2014 [Available from: https://sustainabledevelopment.un.org/partnership/?p=34566.

[3] S. H. Kim, S. K. Han and H. S. Shin, "Feasibility of biohydrogen production by anaerobic co-digestion of food waste and sewage sludge," International Journal of Hydrogen Energy, vol. 29, pp. 16071616,2004

[4] M. Sharholy, K. Ahmad, G Mahmood, R. Trivedi, "Municipal solid waste management in Indian cities-A review," Waste management, vol. 28, pp. 459-67, 2008.

[5] M. S. Prabhu and S. Mutnuri, "Anaerobic co-digestion of sewage sludge and food waste," Waste management research, vol. 34, pp. 307$315,2016$.

[6] C. Y. Lin, F. Y. Bian and J. Chou, "Anaerobic co-digestion of septage and landfill leachate," Bioresource technology, vol. 68, pp. 275-282, 1999.

[7] D. Lu, X. Liu, O. G. Apul, L. Zhang, D. K. Ryan, X. Zhang, "Optimization of biomethane production from anaerobic Co-digestion of microalgae and septic tank sludge," Biomass Bioenergy, vol. 127, pp. 105-266, 2019.

[8] S. Kashi, B. Satari, M. Lundin, I. S. Horváth and M. Othman, "Application of a mixture design to identify the effects of substrates ratios and interactions on anaerobic co-digestion of municipal sludge, grease trap waste, and meat processing waste," Journal of environmental chemical engineering, vol. 5, pp. 6156-6164, 2017.

[9] L. Zhang, W. Ouyang and A. Lia, "Essential role of trace elements in continuous anaerobic digestion of food waste," Procedia Environmental Sciences, vol. 16, pp. 102-111, 2012.

[10] GSPCB. Annual report [Available from: http://goaspcb.gov.in/Media/Default/uploads/2)\%20Muincipal\%20Sol id\%20Waste\%20Management.pdf.

[11] Q. M. Nguyen, D. C. Bui, T. Phuong, V. H. Doan, T. N. Nguyen and M. V. Nguyen, "Investigation of Heavy Metal Effects on the Anaerobic Co-Digestion Process of Waste Activated Sludge and Septic Tank Sludge," International Journal of Chemical Engineering, 2019.

[12] R. Curry and M. Pérez-Camacho , "BioGas to BioRefinery. Life Cycle Analysis of advanced utilisation options for anaerobic digestion using the anaerobic Biorefinery concept," Journal of Cleaner Production, 2017.

[13] M. Mel, A. S. Hisham Yong, A. Avicenna, S. I. Ihsan and R. Hendroko, "Simulation study for economic analysis of biogas production from agricultural biomass," Energy Procedia, vol. 65, pp.204-214, 2015.

[14] R. Chavan and S. Mutnuri, "Demonstration of pilot-scale integrative treatment of nitrogenous industrial effluent for struvite and algal biomass production," Journal of Applied Phycology, vol. 32, pp. 1215$1229,2020$.

[15] APHA. Standard methods for the examination of water and wastewater, 1985.

[16] F. Raposo, M. De la Rubia, R. Borja and M. Alaiz, "Assessment of a modified and optimised method for determining chemical oxygen demand of solid substrates and solutions with high suspended solid content," Talanta, vol. 76, pp. 448-453, 2008

[17] S. L. Wang, "Microwave oven drying method for total solids determination in tomatoes: collaborative survey," Journal of the Association of Official Analytical Chemists, vol. 70, pp. 758-759, 1987.

[18] B. Zhu, P. Gikas, R. Zhang, J. Lord, B. Jenkins, X. Li, "Characteristics and biogas production potential of municipal solid wastes pretreated with a rotary drum reactor," Bioresource technology, vol. 100, pp.1122-1129, 2009.

[19] J.B. Angeli, A. Morales, T. LeFloc'h, A. Lakel, Y. Andres, “Anaerobic digestion and integration at urban scale: feedback and comparative case study," Energy, Sustainability Society, vol.8, pp.1-23,2018.

[20] C. Stan, G. Collaguazo, C. Streche and T. Apostol, Cocarta DM. Pilotscale anaerobic co-digestion of the "OFMSW: Improving biogas production and startup," Sustainability, vol. 10, pp. 1939, 2018.

[21] M. Gao, L. Zhang and Y. Liu, "High-loading food waste and blackwater anaerobic co-digestion: Maximizing bioenergy recovery," Chemical Engineering, vol.12, pp. 4911, 2020.

[22] S. Isaksson, "Biogas production at high ammonia levels: The importance of temperature and trace element supplementation on microbial communities," 2018. 
[23] K. Sheng, X. Chen, J. Pan, R. Kloss, Y. Wei and Y. Ying, "Effect of ammonia and nitrate on biogas production from food waste via anaerobic digestion," Biosystems Engineering, vol.116, pp. 205-212, 2013.

[24] O. Marín-Peña, A. Alvarado-Lassman, N. A. Vallejo-Cantú, I. JuárezBarojas,J. P. Rodríguez-Jarquín and A. Martínez-Sibaja, "Electrical Conductivity for Monitoring the Expansion of the Support Material in an Anaerobic Biofilm Reactor," Processes, vol. 8, pp. 77, 2020.

[25] Y. Li, S. Y. Park and J. Zhu, "Solid-state anaerobic digestion for methane production from organic waste," Renewable sustainable energy reviews, vol.15, pp. 821-826, 2011.

[26] C. Nzila, J. Dewulf, H. Spanjers, D. Tuigong, H. Kiriamiti and H. Van Langenhove, "Multi criteria sustainability assessment of biogas production in Kenya," Applied Energy, vol.93, pp. 496-506, 2012.

[27] P. Boonsawang, A. Rerngnarong, C. Tongurai and S. Chaiprapat, "Effect of nitrogen and phosphorus on the performance of acidogenic and methanogenic reactors for treatment of biodiesel wastewater," Journal of Science \& Technology, vol. 36, pp. 643-649, 2014.

[28] P. Weiland, "Biogas production: current state and perspectives," Applied microbiology Biotechnology, vol. 85, pp. 849-860, 2010.

[29] R. Klein, V. Slaný and E. Krčálová, "Conductivity measurement for control of a biogas plant," Acta Universitatis Agriculturae et Silviculturae Mendelianae Brunensis, vol. 66, pp. 1151-1156, 2018.

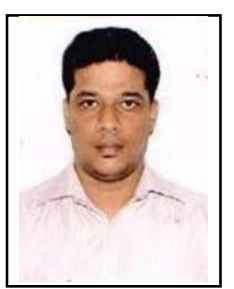

Ravikiran Shet is a research fellow at Birla Institute of Technology and Science, KK Birla Goa campus Goa, India. Author has master's degree in Environmental Engineering. Author is currently working on solid waste management and bioenergy. Author has worked on terra preta sanitation project and demonstration of waste to energy project by anaerobic co-digestion of organic waste and septage. The author has research interests in enzyme pretreatment for higher biogas yield, enrichment of

biogas purity using bio scrubbers.

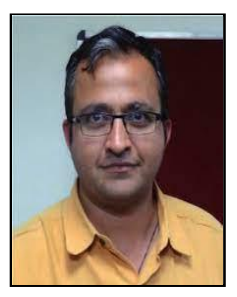

Dr. Srikanth Mutnuri is presently working as Professor at Birla Institute of Technology and Science, KK Birla Goa campus Goa, India. Author has PhD from Research work conducted at Helmholtz Centre for Environmental Research, Leipzig Germany under DAAD Sandwich fellowship in the year 2004. The author has published articles in several international journals. The author has research interests in the fields of microbiology, solid waste management, waste water treatment and water treatment. 